\title{
Erratum to: Effect of ramial wood amendment on sorghum production and topsoil quality in a Sudano-Sahelian ecosystem (central Burkina Faso)
}

\author{
Bernard G. Barthès • Aurélien Penche $\cdot$ Edmond Hien $\cdot$ Philippe Deleporte \\ Cathy Clermont-Dauphin $\cdot$ Laurent Cournac $\cdot$ Raphaël J. Manlay
}

Published online: 18 November 2014

(C) Springer Science+Business Media Dordrecht 2014

\section{Erratum to: Agroforest Syst DOI 10.1007/s10457-014-9743-0}

Unfortunately, in the original publication of the article, Table 1 layout has appeared incorrectly. The correct version of Table 1 is provided in this erratum.

The online version of the original article can be found under doi:10.1007/s10457-014-9743-0.

B. G. Barthès $(\bowtie) \cdot$ C. Clermont-Dauphin · L. Cournac IRD, UMR Eco\&Sols, Montpellier SupAgro, 34060 Montpellier Cedex 2, France

e-mail: bernard.barthes@ird.fr

\section{A. Penche $\cdot$ E. Hien}

IRD, UMR Eco\&Sols, 01 BP 182, Ouagadougou 01, Burkina Faso

\section{A. Penche}

Société Lecofruit, Tsaralalana, Antananarivo, Madagascar

E. Hien

UFR Science de la Vie et de la Terre, Université de Ouagadougou, 03 BP 7021, Ouagadougou 03,

Burkina Faso
P. Deleporte

Cirad, UMR Eco\&Sols, Montpellier SupAgro,

34060 Montpellier Cedex 2, France

R. J. Manlay

AgroParisTech, UMR Eco\&Sols, Montpellier SupAgro, 34060 Montpellier Cedex 2, France 


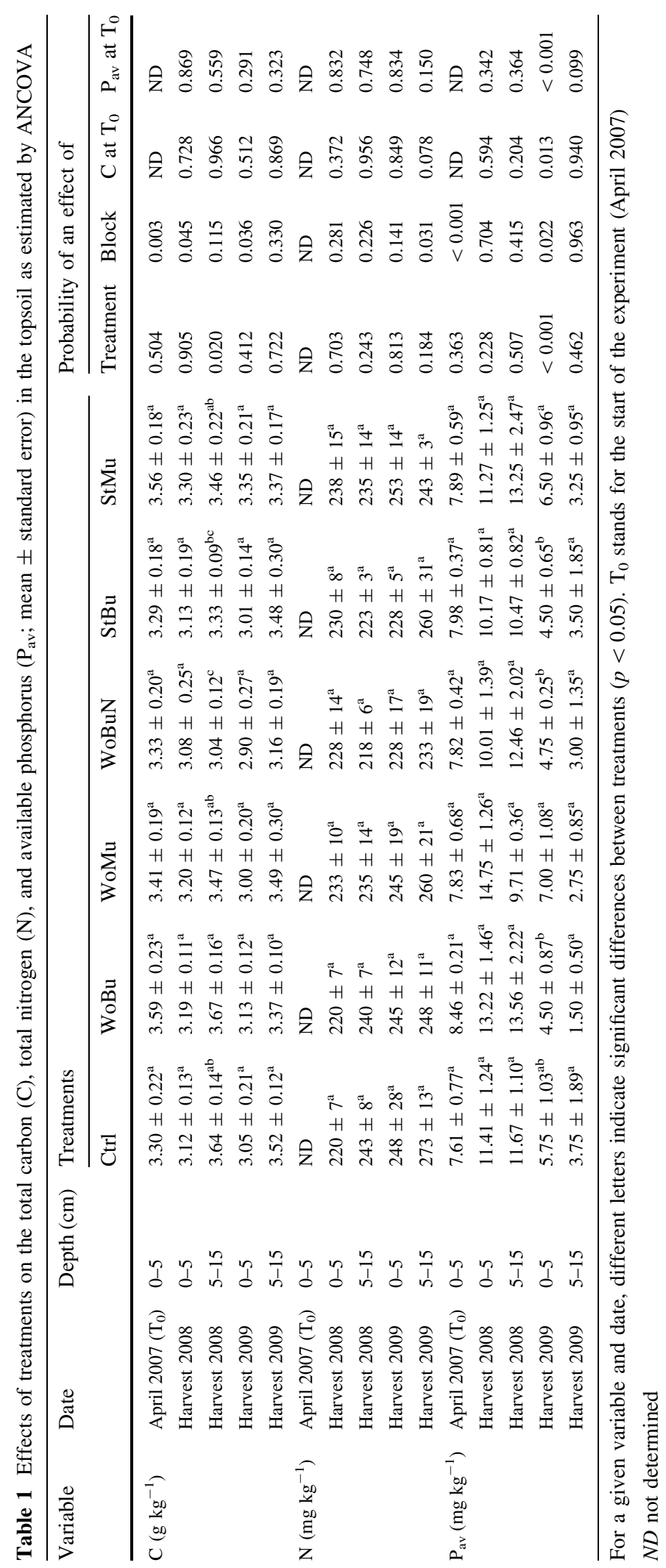

